\title{
What American Century?
}

\section{Citation}

Darnton, Robert. 1999. What American century? European Review 7(4): 455-459.

\section{Published Version}

http://dx.doi.org/10.1017/S1062798700004385

\section{Permanent link}

http://nrs.harvard.edu/urn-3:HUL.InstRepos:3403040

\section{Terms of Use}

This article was downloaded from Harvard University's DASH repository, and is made available under the terms and conditions applicable to Other Posted Material, as set forth at http:// nrs.harvard.edu/urn-3:HUL.InstRepos:dash.current.terms-of-use\#LAA

\section{Share Your Story}

The Harvard community has made this article openly available.

Please share how this access benefits you. Submit a story.

\section{Accessibility}




\section{What American century?}

\section{ROBERT DARNTON*}

As the year 2000 approaches there is a seemingly irresistible tendency to attach a label to the century that is ending. We here everywhere of "The American Century", as if a stretch of time could belong to a country. Behind that expression, one can detect a set of attitudes, some of them holdovers from the nationalist sentiments that first surfaced in the nineteenth century, others expressions of anti-Americanism: if you don't like something about contemporary culture, blame it on the Yanks. In fact, most of the phenomena currently associated with America are global in nature, and the notion of an American Century makes little sense, except at the level of collective mentalities. Still, if one must associate a century with America, the best candidate would be the eighteenth. During the age of Enlightenment and Revolution, America epitomized everything enlightened and revolutionary. And Americans in Paris could bask in the glory of being identified not with McDonald's nor with Hollywood but rather with republican virtue and the rights of man. The real American century came to an end two hundred years ago.

Is this the American century? Hardly. The American century began three hundred years ago and ended in 1800 . That view may not command universal consent; but before defending it, permit me to challenge those who claim that the 20th century somehow belongs to America, by which they mean the United States. Speaking as an American myself, I don't want it. It was a terrible century. I grant you dental hygiene and mountain bikes; but world wars, global pollution, runaway demography, genocide and totalitarianism? No thanks.

True, you encounter the expression everywhere. A quick check on the Web turned up 691 entries for 'the American century' - most of them, admittedly, concerning real estate and banking (e.g. the American Century Bank in Stockbridge, Georgia: 'Call Debbie or Carol,' with their phone number, etc). Why this proclivity to proclaim ownership over a stretch of time? On the part of the Americans, it may betray a childish ambition to rank as number 1; among Europeans, it often provides cover for anti-Americanism: if you don't like the century, blame it on the Yanks. However misguided, both views reveal some unfamiliar aspects of general attitudes or 'collective mentalities.' Let me explain.

Nations do not have numbers; but if you look them up in the international pages of a telephone directory, you do indeed find a numerical order. The United States is first, although it shares number one with Canada and the Dominican Republic; France is 33; Britain, 44; Germany, 49; Brazil, 55; Albania, 355 and Bangladesh 880. Closer inspection reveals some logic behind the numbering. African countries have numbers that begin with 2, South American

\footnotetext{
* Department of History, Princeton University, 129 Dickinson Hall, Princeton NJ 08544-1017, USA. E-mail:
} darnton@princeton.edu 
countries with 5, Asian countries with 8 . But why should the United States take first place? Presumably because it got there first when the system was devised, or because it devised the system.

The same principle applies to the World Wide Web. If you send e-mail to anyone with a non-American address, you have to add an indication for a country at the end: fr for France, uk for Britain, de for Germany. For the United States, you put nothing, because e-mail began in the US and then spread to the rest of the world. It is as if the Americans owned the Internet. To e-mailers around the globe, it must be galling - a sign, perhaps, that Americanization takes the form of a communications empire, sending invisible tendrils through the ether and pulling everyone into its grasp.

That way of thinking is symptomatic of a new false consciousness, a post-Marxist variety, because electronic communication does not coincide with a country. It is supranational by its very nature. So are most of the things that we associate with the century beginning or ending in the year 2000. They may come with an American accent, but they have no anchorage anywhere. Multinational companies, capital flows, labour markets, global warming, divorce rates, soap operas, t-shirts, hard rock, post-modernism, AIDS - all these phenomena spill over national boundaries and cannot be identified exclusively with the United States. That became clear at the last Olympics, when Cuba beat the US in baseball.

Nonetheless, citizens of the world, however worldly, persist in condemning the US for everything that offends them about the current state of culture. The French will not allow more than a small percentage of the music on their radios to come from America. The Belgians won't allow Coke - or didn't for ten days in June 1999. If you suffer from any variety of mal du siècle, you call it American. The mal is actually a fin du siècle phenomenon, a resurgence of anti-Americanism. Far from marking the American century therefore, the year 2000 stands as a signpost of the anti-American century, one that began around 1950 and is still going strong.

Anti-Americanism is a fact of collective consciousness, and it cannot be dispelled simply by invoking counter-facts. For example, sociologists have developed an index that ranks the prevalence of corruption, country by country, according to opinion polls. New Zealand comes in first - that is, it is generally perceived to be the least corrupt country in the world. Denmark is number 2, Britain 12, Germany 13, the United States 15, France 19, Brazil 40 and Bangladesh 51. For my part, I think New Zealand is a lovely country: nice people, beautiful scenery, an adequate welfare system, a decent standard of living for everyone (there are difficulties, admittedly, with the Maori, but the New Zealanders are working on them). So I would like to propose that we call our era the New Zealand century.

It won't work, of course. There is no convincing alternative to the rating system that consigns this century to America, nor is there an antidote to the anti-Americanism that accompanies it. Resentment of the United States appears to be built into the post-Cold War world. Now that the Soviet Union has collapsed, Japan is sinking, Brazil has not yet risen, and China remains inscrutable, the world is stuck with a single superpower. Quite understandably, the world does not like it. Neither do the Americans. They may try to emigrate to New Zealand - or other small places that get big scores on rank lists, such as The Netherlands (very high income per capita) or Denmark (very little corruption) or the Republic of San Marino (little in all respects, except its postal code, a whopping 378). But they cannot escape from anti-Americanism.

They may, however, have escapist fantasies. Mine go back to the real American century; that is, the 18th. Imagine being an American in Paris in the 1780s. Instead of being blamed 
for McDonald's when you walk along the boulevards, you get congratulated for defending the Rights of Man. You needn't worry about the unfashionable cut of your clothes: that confirms your closeness to the order of nature. Do you mispronounce some words or get their gender wrong? A sign of savage eloquence. Do you fail to catch allusions or misunderstand some repartee? A symptom of virtue, perhaps even of Quakerism. If you don't know Benjamin Franklin, you can quote some folksy proverb from Le Bonhomme Richard (Poor Richard's Almanac). If you never dined with Jefferson, you can dine out on stories about how you drove the British from your home town. The possibilities of evoking smiles instead of frowns were endless, because there was no end to the French fascination with America.

I once gave vent to this escapism by reading every issue of France's only daily newspaper, Le Journal de Paris, from 1780 to 1789. 1 encountered American themes and enthusiasm for America nearly everywhere. The biggest hit among the vaudeville theatres in 1786 was $\mathrm{La}$ Héroine américaine at the Ambigu-Comique. A rival troupe, Les Grands Danseurs du Roi, offered its own variation on the same theme, Le Héro américain, a 'pantomime in three acts, with dialogue, dances, music and combat', while upmarket, the Comédie Italienne staged a Ballet des Quakers. By then D'Hirza ou les Illinois had finished its run on the boulevards, but the connoisseur of Indian oratory - a favourite genre in pre-romantic Paris - could read native-American odes to Nature in the 'anecdotes' column of the paper. Better yet, he could procure great chunks of Iroquois and Illinois translated into Rousseauistic French in Le Voyageur américain and Le Cultivateur américain available in bookshops throughout the Latin Quarter.

For a glimpse of a noble savage in the flesh, one could walk past La Fayette's residence, where two Indians served as houseboys. La Fayette himself, staring fiercely at the enemy at Yorktown, could be admired in prints exposed in shop windows all along the rue Saint Jacques. Washington, too, could be purchased for a few pennies and pinned to one's wall, along with other stock figures - Virginia planters, Pennsylvania Quakers, Nantucket whalers - from prints and books. Franklin was everywhere - as 'Le Bonhomme Richard,' the incarnation of common sense and the common man in everybody's almanac, as a statesman negotiating with the great under a coonskin cap at Versailles; and as a philosopher, sublimely bald, taming lightning from the sky or discoursing on electricity before the Academy of Sciences.

Thomas Jefferson, Franklin's successor as representative of the new republic, arrived in the wake of a wave of publications about the American Revolution. Jefferson's own Remarques sur la Virginie could be sampled in the book review section of the Journal de Paris, along with extracts from the memoirs of several French veterans of the War of Independence and the occasional novel, like Miss Mac Rea, a revolutionary romance. Even more romantic were the coiffures 'à la Philadelphie' and 'aux Insurgents' advertised in the newspaper and exhibited by stylish ladies at the Opera and the Comédie française.

The fashion for everything American reached such proportions that it threatened to provoke a surge of emigration to the New World. Franklin and Jefferson received many letters from starry-eyed Frenchmen determined to start life over again as homesteaders. 'You are made to legislate for us, because for us you are men from the Golden Age,' wrote one potential immigrant to Jefferson. 'Ah, Monsieur, your land is the promised land... How happy would I be to exist in such a fine country, where I would be a man instead of a slave as I am here.' Jefferson did what he could to counteract this utopian enthusiasm by providing information 
about the realities of life in America. He spent hours weeding out inaccuracies from the article on the United States that J.-N. Demeunier wrote for the Encyclopédie méthodique; and even so, he remained dissatisfied with the final text: 'He has left in a great deal of the abbe Raynal, that is to say a great deal of falsehood.'

Raynal's best-selling Histoire philosophique et politique des établissements et du commerce des Européens dans les deux Indes was but one of the many books that fed the growing debate about the meaning of America and its relevance for Europe. Frenchmen of all stripes posed as American experts and even adopted American identities in order to further their arguments. Jacques-Pierre Brissot wrote as a 'Philadelphien' and a founding member of the Société Gallo-Américaine, Hector Saint Jean de Crèvecoeur as a 'cultivateur américain,' Beaumarchais as 'Beaumarchais l'Américain,' and Condorcet as a 'bourgeois de New Haven.' Their polemics - for they disagreed about everything, even the virtue of Quakers - only increased the interest in this extraordinary phenomenon: a modern republic - not a decadent oligarchy or a commercial autocracy as in the pseudo-republics of Venice and Geneva, but an egalitarian order of small farmers, good family men (as the French imagined them) with virtuous wives, numerous children, and well-stocked granaries.

Condorcet, coached by Jefferson, represented the more realistic side of the polemics, but his view of America remained decidedly utopian. In fact, it became a crucial ingredient in the early version of his theory of progress, which appeared in a tract of 1786 , De l'influence de la révolution d'Amérique sur l'Europe, dedicated to La Fayette:

America offers the prospect of a vast land populated by several million men who, thanks to
their education, have been made immune to prejudice and inclined to study and reflection. No
distinction of rank or pull of ambition can deter these men from the natural desire to perfect
their minds, to apply their intelligence to useful research ... . There is therefore reason to hope
that by producing as many men devoted to the increase of knowledge as in all of Europe,
America will in a few generations double the mass of knowledge and the speed of its
accumulation. This progress will take place equally in the useful arts and the speculative
sciences.

Seen from the end of the 20th century, Condorcet's prophecy looks woefully inaccurate, and the American fashion in France may be dismissed as another case of false consciousness - worth considering as an ideological element in the coming of the French Revolution but not as an account of the America that actually existed. The actual American republic was marked at its birth with an original sin: slavery - a curse visited upon us by the merchants of Nantes and Newcastle-upon-Tyne and that we acknowledged in our Constitution.

Yet the Constitution is a remarkable document. The basic text contains only 5000 words, drafted in the midst of strenuous debate and uninhibited horse trading during a hot summer in 1787 , but it bound 13 disparate states together in a polity that survived a horrendous civil war and developed from a primitive agrarian economy into the most powerful industrialized nation in the world. The Founding Fathers look more impressive as they recede further back in time. One can take their measure by reading the letters exchanged between Jefferson and Madison. They discussed politics with a combination of down-to-earth realism (how to stay clear of European wars and yet take effective action against the Barbary pirates?) and philosophical daring (can the social contract bind future generations?). For intellectual 
firepower, no other presidents come close to them, certainly not anyone who has occupied the White House in recent memory.

The constituents of the Founding Fathers also command respect. They may not have been noble savages, but they were serious citizens, possibly more literate, at least in New England, than most Americans today. Of course, they had one advantage over us: they lacked television. So in every settlement they read newspapers, discussed the issues, wrote letters to the editors, and attended town meetings or sessions in county courthouses. A large majority of the 700000 free adult males in the 13 states participated actively in discussions of every aspect of the proposed Constitution in 1787-1788 - the greatest political debate in the history of the nation. And the greatest product of it, The Federalist Papers, written at white hot speed in the form of newspaper articles for a dozen different audiences, still stands out today as a masterpiece of political science.

In the end, many citizens accepted the Constitution only with reservations and due to assurances that it would be completed with amendments protecting basic civil rights. Those ten amendments, proposed by Madison to the First Congress in 1789 and known as the Bill of Rights, embodied many of the Enlightenment principles that Madison had discussed with Jefferson. For two centuries they have kept the government at bay. They have prevented politicians from interfering with the press, Bible thumpers from forcing religion into schools, the FBI from opening letters, and the CIA from tapping telephones. I doubt that they would be passed by Congress and ratified by state governments today, because they are too enlightened for the politics of the so-called American century.

Of course, there is something absurd about the idea of sticking a label on a century and awarding it to a country. We historians bear part of the responsibility for foisting this notion on the public, because the history we write has often turned on calculations of hegemony. Who was on top in the 16th century? Habsburg Spain and Austria. In the 17th century? France. In the 18th and 19th centuries? Great Britain and then Germany. It remained for America to tip the balance of power after World War I. But why should any country have the greatest weight? The idea derives from a view of history as a competition of nation-states, in which one must always predominate: hence the concept of 'prépondérance' written into titles like $\mathrm{La}$ prépondérance espagnole (1559-1660) and La prépondérance anglaise (l715-1763) in the classic 'Peuples et civilisations' series in France.

This way of slicing time may have made some sense in an age of nationalism but not in an era of globalization. I propose that we abandon it. But if we must bestow a century on a country and if one of those countries must be the United States, my choice is clear. I don't want to minimize the feats of rocketry and dentistry, or the importance of hybrid corn and computerized air traffic; but my American century would be the century of the Bill of Rights.

\section{About the Author}

Robert Darnton is Shelby Cullom Davis Professor of European History at Princeton University. He is also President of the American Historical Association, a Foreign Member of the Academia Europaea and an Editor of this European Review. 